\title{
Organizational entrepreneurship and the political
}

\author{
Daniel Hjorth, Copenhagen Business School (CBS), Denmark \\ Robin Holt, CBS, Denmark \\ Pablo Fernandez, IAE Business School, Argentina \\ Carine Farias, ISTEC Paris, France and CBS
}

This special issue proposal encourages submissions investigating the socio-political nature of entrepreneurship processes. As the creation of new organizational form, entrepreneurship challenges the established, settled, institutionalized, habituated nature of what already has been organized. By opening up and moving in the inbetween spaces of an organizational domain of activities entrepreneurial action often publicly brings people to the edge of habits and tradition, making them aware of what Schumpeter called the 'pale of routine.' It is in making this move toward the edges attractive enough that we witness entrepreneurship as an organizational creation-process. When this takes place in the context of existing organizations, there is a whole range of socio-political challenges that requires our further study.

In this association of entrepreneurship and organization-creation we find a growing awareness that the entrepreneurial is not synonymous with economic enterprise, despite their frequent association. Indeed, we might argue this association is itself a political move (Hjorth, 2003). Enterprise associates specific organizational structures (ventures, markets), human qualities (risk taking, boldness, self-reliance), norms of social and economic de-regulation, and certain effects (scaled innovation, profit, acquisition, mobility, wealth creation), all of which is couched in a language of material resuscitation and growth (Anderson and Warren, 2011; Dodd et al, 2013; du Gay, 2004; McNay, 2009; Parker, 2002; Sturdy and Wright, 2008). Here the locus of curiosity and inquiry so valued by enterprise is framed by a specific sense of the political which envisages groups of homo oeconomicus agents living in competitionbased individuality, deciding whether, on a basis of a normative recognition of shared needs, to build relationships with one another (Massumi, 2002). In contrast, entrepreneurship can be understood simply as a creative process in which the new is being brought to fruition through creation of organization (Spinosa et al, 1997). As such it can run against enterprise, especially if we acknowledge that the urge toward the self-reliance characterising enterprising activity is scripted through managerial direction and an economic logic of producing more with less. In bringing about what is new through a social, collective processes, entrepreneurship always challenges short-term economic rationality that is badly fitted to handle uncertainty without constant references to the manager's ' gut feeling.' Moving beyond existing edges provokes the question of the political. The dawn of the new brings potentially destructive forces by transgressing and involving what is "out of place" (Douglas, 2002), and is thus always accompanied by the politics of finding a new order.

Zahra, Newey, and Li (2013: 143) point out that this awareness of the intimacy between entrepreneurship and the socio-political stretches right back to Schumpeter for whom entrepreneurial ventures were allocators of social wealth. Yet only recently, has this been recovered. Arguably, enterprise discourse, sailing under the 
flag of entrepreneurship, has made the social into an epiphenomenon to economy. The result has been a managerial definition of entrepreneurship - more properly named enterprise - where human capital models dominate. As a consequence, the political falls outside the domain of attention for the analyst seeking to explain what is going on using standard business models. Following Steyaert and Hjorth (2004), Zahra et al (2013) and Hjorth and Holt (2016) we thus stress the importance of not collapsing the distinction between enterprise and entrepreneurship. Moreover, we find it artificial to try to understand entrepreneurship when the political and social are added. We seek to understand the immanently sociopolitical nature of entrepreneurship (cf. ERD Special Issue, 2013; Down, 2013) in the context of established organizational spaces (Hjorth, 2005; Beyes and Steyaert, 2012).

In this sense we conceptualize the entrepreneurial condition as those moments, spans of creative, collectively woven 'blocs of becoming' that breach the singular pursuit of economic returns under a compulsion that life might somehow be organized differently (Massumi, 2015; Deleuze and Guattari, 1987: 10; cf. Sloterdijk, 2013). This difference is actualized through collective organizational action. In our attempt to better understand the nature of such processes of organizational entrepreneurship, creating the conditions for the new to achieve being, we stress the need to focus on the sociopolitical. Making newness incipient requires the invention of potential, intensifying our capacity to identify where 'buds of tendency' are emerging (Massumi, 2015). "According to Schumpeter, the giant firm saps entrepreneurship of its vital force by trying to be entrepreneurial in a purely rational manner." (Swedberg, 2012: 38). Schumpeter says that its element of 'romance' is eliminated: "The romance of earlier commercial adventure is rapidly wearing away, because so many more things can be strictly calculated that had of old to be visualized..." (Schumpeter, 1942: 152). Massumi calls the invention of potential fabulation (2015: 54) and although Massumi writes in a time more attuned to the importance of narrative, there are clear similarities to Schumpeter's visualization.

This special issue is interested in how we should describe, analyse and study this tendency of established organizations to extract romance and adventure from entrepreneurship, reducing it to the economy of a venture. Although we do not intend to limit this special issue to the managerial and strategic horizon often dominating corporate entrepreneurship research (e.g. Burgelman, 1983; Stopford and Baden-Fuller, 1994; Zahra, 1991; Covin and Miles, 1999; Kuratko et al., 2004; Hornsby et al., 2009), it seems important to note that this field of research has not been particularly attentive to the socio-political problem of organizational entrepreneurship. In Schumpeter's terms, this special issue is thus inviting authors to an adventure where there is still romance to be had in the thrill of creating knowledge.

We are interested in submissions that might address, but need not be limited to, the following:

o Acts of tactical 'making use' of cracks in the strategic grid (cf de Certeau, 1984) which might be anonymous (work on subterfuge, trap doors, invisible, short, small and rapid) and ambivalent (ironic, humorous, vague, ambiguous).

o Entrepreneurship, ethics and autonomy (Clarke and Holt, 2010). 
o The politics of organizational entrepreneurship as exemplified in corporate entrepreneurship and creative, transformative acts of resistance in organizational and institutional contexts (Courpasson, Dany, and Marti, 2014)

o The organizational politics of newness as examples of provocative 'making room', 'creating space' for creation and innovation in institutional and organizational contexts (Hjorth, 2011).

o The politics of play, humour, the vague, and ambiguous as a genre of entrepreneurial action.

o Historical studies in 'entrepreneurship' and wider political and social conditions (Wadhwani and Jones, 2014).

o The 'dark side' of entrepreneurial destruction as a condition for and consequence of newness.

o The socio-political process of entrepreneurship in the context of societal transformation and change (as exemplified in social- or public entrepreneurship; Daskalaki, Hjorth, and Mair, 2015).

o Historical perspectives on the politics of enterprise and entrepreneurship.

\section{Notes for prospective authors}

Submitted papers should not have been previously published nor be currently under consideration for publication elsewhere. Papers regarded as potentially suitable for publication in the Special Issue will be double-blind reviewed following the ERD's review process guidelines.

Full papers must be in a Word-compatible format and emailed to Daniel Hjorth (dh.mpp@cbs.dk) and Robin Holt (rh.mpp@cbs.dk). The first page of the manuscript must contain title, author(s), affiliation(s) and contact information (including email address) for the corresponding author. No identity information should be found elsewhere on the manuscript. For additional guidelines on style/referencing, please see the ERD's Instructions for Authors, in particular the section on Manuscript Preparation.

Manuscripts must be received by no later than March 31 ${ }^{\text {st }}$ 2017. While general queries may be directed to any of the Special Issue editors (dh.mpp@cbs.dk, rh.mpp@cbs.dk, pfernandez@iae.edu.ar, carine.m.farias@gmail.com), the final submission must be sent to Daniel Hjorth and Robin Holt (see email addresses above).

\section{References}

Anderson, A. and Warren, L. (2011) “The entrepreneur as hero and jester: Enacting the entrepreneurial discourse," International Small Business Journal, 29(6): 589-609.

Arendt, H. (1958) The Human Condition, Chicago: University of Chicago Press,

Beyes, T. and Steyaert, C. (2012) "Spacing organization: non-representational theory and performing organizational space," Organization, 19(1): 45-61.

Burgelman, R. A. (1983). Corporate entrepreneurship and strategic management: insights from a process study. Management Science , 29: 1349-1364. 
Clarke, J, Holt, R (2010) “The mature entrepreneur". Journal of Management Inquiry, 19(1): 69-83

Courpasson, D., Dany, F., and Marti, I. (2014) “Organizational Entrepreneurship as Active Resistance: A Struggle against Outsourcing," Entrepreneurship, Theory \& Practice, Article first published online: 21 APR 2014

DOI: 10.1111/etap.12109De

Covin, J. G. and Miles, M. P. (1999). Corporate entrepreneurship and the pursuit of competitive advantage. Entrepreneurship Theory and Practice , 23 (3), 47-64.

Certeau, M. (1984) The Practice of Everyday Life, Berkeley: University of California Press.

Daskalaki, M., Hjorth, D., and Mair, J. (2015) “Are Entrepreneurship, Communities, and Social Transformation Related?", Journal of Management Inquiry, Published online before print April 5, 2015, doi: 10.1177/1056492615579012

Deleuze, G. and Guattari, F. (1987) A Thousand Plateaus - capitalism and schizophrenia, London: The Athlone Press.

Dodd, S., Jack, S., Anderson, A. (2013) 'From admiration to abhorrence: The contentious appeal of entrepreneurship across Europe', Entrepreneurship \& Regional Development, 25(1-2): 69-89.

Douglas, M. (2003). Purity and danger: An analysis of concepts of pollution and taboo, London: Routledge.

Down, S. (2013) 'The distinctiveness of the European tradition in entrepreneurship research', Entrepreneurship and Regional Development, 25(1-2): 1-4.

du Gay, P. (2004) Against enterprise (But not against "enterprise", for that would make no sense), Organization, 11(1): 37-57.

Hjorth, D. (2005). Organizational entrepreneurship. With de Certeau on creating heterotopias (or spaces for play). Journal of management inquiry, 14(4), 386-398.

Hjorth, D. (2011) On provocation, education and entrepreneurship. Entrepreneurship and Regional Development, 23(1): 49-63

Hjorth, D., Holt, R. (2016) 'Its entrepreneurship, not enterprise: Ai Weiwei as an entrepreneur' Journal of Business Venturing Insights, 5: 50-54.

Hornsby, J. S., Kuratko, D. F., Shepherd, D. A. and Bott, J. P. (2009). Managers' corporate entrepreneurial actions: examining perception and position. Journal of Business Venturing , 24 (3), 236-247.

Kuratko, D. F., Hornsby, J. S. and Goldsby, M. G. (2004). Sustaining corporate entrepreneurship: a proposed model of perceived implementation/outcome comparisons at the organizational and individual levels. International Journal of Entrepreneurship and Innovation , 5 (2), 77-89. 
Massumi, B. (2002) Parables for the Virtual - movement, affect, sensation, Durham: Duke University Press.

Massumi, B. (2015) The Power at the End of Economy, Durham and London: Duke University Press.

McNay, L. (2009) Self as Enterprise: Dilemmas of control and resistance in Foucault's The Birth of Biopolitics, Theory, Culture \& Society, 26(6): 55-77.

Parker, M (2002) Against Management: Organization in an Age of Managerialism London: Polity Press.

Schumpeter, J. A. (1942) Capitalism, Socialism and Democracy. New York: Harper and Row.

Sloterdijk, P. (2013) You must change your life, Cambridge: Polity Press.

Spinosa, C., Flores, F., \& Dreyfus, H.L. (1997). Disclosing new worlds: entrepreneurship,democratic action, and the cultivation of solidarity. Cambridge, Mass.: MIT Press.

Steyaert, C. and Hjorth, D. (Eds.)(2004) New Movements in Entrepreneurship, Cheltenham: Edward Elgar.

Stopford, J. M. and Baden-Fuller, C. W. F. (1994). Creating corporate entrepreneurship. Strategic Management Journal , 15 (7), 521-536.

Sturdy, A., Wright, C. (2008) A consulting diaspora? Enterprising selves as agents of enterprise. Organization, 15(3): 427-444

Swedberg, R. (2012) "Schumpeter's theories of organizational entrepreneurship," in Hjorth, D. (Ed.) Handbook on Organisational Entrepreneurship, Cheltenham: Edward Elgar, pp. 31-48.

Wadhwani, R. D., \& Jones, G. (2014). Schumpeter's Plea: Historical Reasoning in Entrepreneurship Theory and Research. In M. Bucheli \& R.D. Wadhwani (Eds.) Organizations in Time: History, Theory, Methods. pp. 192-216. Oxford: Oxford University Press.

Zahra, S. A., Newey, L. R., and Li, Y. (2014) "On the Frontiers: The Implications of Social Entrepreneurship for International Entrepreneurship," Entrepreneurship, Theory \& Practice, 38(1): 137-158. 